\title{
Ю. Дишкантюк,
}

\section{ПОНЯТТЯ Й ОЗНАКИ ПОСЛУГИ ЯК ПРЕДМЕТА ГОСПОДАРСЬКО-ПРАВОВОГО РЕГУЛЮВАННЯ}

Послуга є важливим чинником господарського права як науки та самостійною правовою категорією, якій притаманний зміст, форма й інші складники. Послуги використовуються різними галузями права, що також свідчить про іï комплексний характер із правового погляду. Проте норми чинного законодавства не визначають поняття й ознаки послуги, а виокремлюють лише деякі аспекти їі правового регулювання, наприклад, фінансові послуги, адміністративні або договір про надання послуг. Господарське законодавство, як загальне - чинний Господарський кодекс України (далі ГК) України [1], так спеціальне, майже не містить відповідного сучасного правового забезпечення окресленої тематики, а тому виникає актуальність зазначеної категорії на доктринальному рівні задля подальшого аналізу й унесення змін у законодавство.

Дослідженнями щодо визначення поняття, ознак і змісту послуг у сфері господарювання займалася низка вчених, як загальних теоретиків-правознавців, так і фахівців 3 адміністративного, цивільного й господарського права, такі як, наприклад, I.I. Беца, T.I. Данилюк, С.І. Плакида, Л.С. Співак, Л.А. Шереметьєва та інші.

Мета статті - дослідження послуги як структурного елемента предмета господарського права з наданням його поняття й ознак, які його виокремлюють і характеризують.

Послуга є правовою категорією, що широко застосовується у сфері господарювання та надається різноманітними суб’єктами, у тому числі й тими, яким притаманні владні повноваження. Для визначення іï змісту й ознак логічним $€$ застосування формально-логічного, діалектичного та системно-структурного методів права.

Послуга є важливою формою господарювання, яка змінюється 3 урахуванням економічних, правових і соціальних потреб. На підставі аналізу норм чинного законодавства можна надати змістовну характеристику послуги, але вони не містять положення щодо виокремлення послуги як самостійної правової дефініції та не надають ii визначення. За частиною 1 ст. 3 ГК України, надання послуг вартісного характеру $є$ складником господарської діяльності, яка, у свою чергу, характеризує предмет господарського права як основна його властивість. Послуга розглядається законодавцем як господарсько-правова категорія, якій притаманний вартісний характер і яка входить до предметного складника господарського права. Наприклад, у законодавстві Польщі послуга теж входить до складу господарської професійної діяльності. За статтею 43-1 Цивільного кодексу Республіки Польща, особи, які $€$ підприємцями, ведуть господарську або професійну діяльність [2], а за ст. 2 Закону «Про свободу господарської діяльності», господарською діяльністю $є$ заробіткова діяльність, у тому числі надання послуг [3]. Тобто виокремлюються вартісний характер послуги, доречним є надання їй статусу професійної діяльності, адже більшість послуг надається саме знавцями - про- 
фесіоналами, вузькокваліфікованими спеціалістами.

Деякі інші вітчизняні нормативні акти містять зазначене поняття стосовно окремих сфер їх правового регулювання. Так, наприклад, за Законом України «Про захист прав споживачів» [4], послуга - це діяльність виконавця 3 надання (передачі) споживачеві певного визначеного договором матеріального чи нематеріального блага, що здійснюється за індивідуальним замовленням споживача для задоволення його особистих потреб. Тут важливим $€$ виокремлення договірної форми послуги й окреслення їі суб'єктно-об'єктного складу. Також заслуговує на увагу минуле нормативне визначення послуги як результату економічної діяльності, що не створює товар, але продається та купується під час торговельних операцій, яке надано в ст. 1 Закону України «Про технічні регламенти та процедури оцінки відповідності» [5]. Тут саме наголошується на господарсько-нормативному визначенні послуги та їі такої властивості як споживання в момент іï надання (реалізаціі). У фінансовому законодавстві послугою визнається будь-яка діяльність (крім виробництва товарів і виконання робіт) [6], тобто зовсім не виокремлюється їі змістова та суб'єктна характеристика. У літературі теж визначається господарське підгрунтя терміна «послуга». Так, наприклад, Л.А. Шереметьєва зазначає, що «у сучасному українському законодавстві поняття «Послуга» тлумачиться як закупівля (товар); результат взаємодії між постачальником і споживачем; певна діяльність чи їі результат; обслуговування; різноманітні заходи, які здійснюються чи пропонуються у різних сферах надання державних та муніципальних послуг, як-то: охорона здоров'я; освіта; громадська безпека; пожежна охорона; соціальне забезпечення; працевлаштування; відпочинок; оподаткування; сфера житлово-комунальних послуг; транспортне обслуговування; сфера фінансових та юридичних послуг тощо.
Особливістю послуг як соціально-економічної категорії $€$ : безпосередній зв'язок (взаємозв'язок) між постачальником та споживачем послуг; неможливість існування послуги окремо від ii виробника (постачальника), а також від споживача» [7, с. 13].

Цікавим є правовий досвід послуг у праві іноземних країн. Так, наприклад, сектор послуг $€$ настільки важливим у Європейському Союзі, що їх належне забезпечення регулюється первинним i вторинним законодавством, зокрема статями Договору про заснування Європейського Союзу та Договору про функціонування Європейського Союзу, окремого Протоколу до нього, а також кількома Директивами, прецедентним правом, Хартією засадничих прав Європейського Союзу. Зокрема, Договір про функціонування Європейського Союзу підкреслює важливість послуг, що забезпечують загальні потреби людини. У статті 14 Договору чітко говориться, що Рада та Парламент установлюють правові принципи щодо надання державних послуг. Ці принципи повинні визначатися шляхом звичайної законодавчої процедури, що в Європейському Союзі означає надання пропозиції Європейською комісією, іï ухвалення Радою та Парламентом [Договір]. Протокол № 26 Договору створює прозору, надійну й міцну основу для надання широкого спектру послуг, що становлять загальносуспільний інтерес включно з економічними та неекономічними послугами. У протоколі № 26 зазначається, що Договір про Європейський Союз і Договір про функціонування Європейського Союзу жодним чином не порушують компетенції держав-членів уповноважувати третіх осіб надавати та організувати послуги неекономічного характеру, що забезпечують загальні потреби [8]. На додаток до чинних чотирьох свобод, що регулюються Договором про функціонування Європейського Союзу, Європейський Союз забезпечує свободу надання послуг з вищезазначеною Директивою про послуги Європейського Пар- 
ламенту й Ради 2006/123 22, низкою рішень Суду ЄС, Хартією основних прав та іншими актами вторинного законодавства. Так, стаття 49 (1) Договору наголошує, що скасовуються будь-які обмеження на вільне надання послуг у межах Союзу стосовно громадян держав-членів, які користуються своїм правом на заснування й підприємницьку діяльність в іншій державі-члені, ніж та, громадянину якої надаються послуги. Стаття 50 (1) Договору визначає поняття послуг, що їх зазвичай надають за винагороду, тією мірою, якою вони не підпадають під дію положень про свободу руху товарів, капіталу та осіб. У статті 50 (2) Договору наводяться види діяльності, які належать до послуг, а саме: діяльність промислового, комерційного характеру, реміснича та професійна діяльність. Спільна політика щодо юридичного регулювання окремих секторів сфери послуг здійснюється на основі окремих нормативних актів, серед них - шість директив (2002/77/ ЕС, 2002/58/EC, $2002 / 22$ / EC, 2002/21/EC, 2002/20/ EC, 2002/19/EC) та одне рішення щодо сфери телекомунікацій; Директива щодо електроенергіі (2003/54/ $\in C)$, Газова директива (2003/55/ ЄC), Поштова директива (97/67/ЄC), Біла книга щодо послуг загальних економічних інтересів (СОM (2004)374), Повідомлення Комісії щодо державно-приватного партнерства, Біла книга «Європейська транспортна політика до 2010 р.: час приймати рішення» [9]. Хартія основних прав містить право на належне управління, доступ до медичного обслуговування, соціального забезпечення тощо. Також варто наголосити, що ст. 36 зазначає, що доступ до послуг, які становлять загальноекономічний інтерес, $€$ основоположним правом. Значну роль у регулюванні сфери послуг відіграв Суд ЄС, який кілька разів виносив рішення щодо послуг загальноекономічного інтересу. Ще у 2000 році прийнята важлива директива $\in C$ щодо електронних послуг стосовно комерції, визначено, що «роз- виток електронної комерції в межах інформаційного суспільства пропонує істотні можливості зайнятості в межах Співтовариства, зокрема, в малих та середніх підприємствах, та стимулюватиме економічне зростання й інвестування європейськими компаніями в інноваційні технології, а також може посилити конкурентоспроможність європейської промисловості, забезпечуючи доступ до Інтернету всім громадянам» [10]. В іншому міжнародному документі наголошується на важливості інформаційних послуг щодо закупівель. Так, у Директиві зазначається, що електронні засоби інформації та комунікації можуть істотно спростити завдання оприлюднення інформації про контракти й підвищити ефективність і прозорість процесів закупівлі. Вони повинні стати стандартним засобом комунікації та обміну інформацією під час процедур закупівлі, оскільки вони істотно розширюють коло можливостей для суб'єктів господарювання щодо участі в процедурах закупівлі на всьому внутрішньому ринку. Зважаючи на це, надання повідомлень в електронній формі, доступність документів щодо закупівлі в електронній формі та після 30-місячного перехідного періоду повністю електронна комунікація, тобто комунікація за допомогою електронних засобів на всіх етапах процедури, у тому числі направлення заявок на участь i, зокрема, направлення тендерних пропозицій (подання в електронній формі), повинні стати обов'язковими [11].

Також Рішення Суду EC забезпечують основу для визначення загальноекономічного інтересу на національному рівні, однак кожне рішення досягається на індивідуальній основі 3 урахуванням умов і національних особливостей держав-членів. Значне роль у галузі послуг, що становлять спільний інтерес, відіграло рішення Суду ЄС від 24 липня 2003 р. у справі С-280/00 Альтмарк Транс, яке встановлює чотири сукупні умови, що визначають надання державних компенсацій за послуги як недержавну 
допомогу [12]. Суд ЄC до категорії послуг зарахував туристичні та комунікативні послуги, будівництво й найм житла, лізинг, увесь спектр фінансових послуг, консультаційні, посередницькі, рекламні послуги, а також послуги, що їх надають лікарі, інженери, архітектори, юристи, тощо. Проте в багатьох випадках регулювання окремих із зазначених сфер здійснюються на основі правових норм стосовно інших свобод.

У літературі існують різну думки щодо визначення послуги та іï виокремлення на підставі певних ознак. Багато вчених пов'язує надання послуг із задоволенням потреб. Так, Л.С. Співак визначає, що послуга - це «результати економічної діяльності, які набувають матеріально-речової форми й задовольняють певні потреби» [13, с. 57]. O. Ланге пропонує, що послугами можна назвати «будь-які функції, які пов'язані ... із задоволенням людських потреб, але які безпосередньо спрямовані на виробництво будь-яких предметів» $[14$, с. 7]. Е.M. Агабаб'ян визначає категорію послуг так: «Під послугою необхідно розуміти корисний ефект, який виникає в процесі продуктивної праці як цілеспрямованої діяльності. Корисний ефект є ні що інше як сукупність корисних властивостей, які спрямовані на задоволення певної потреби людини» [15, с. 24]. Під час надання послуги дійсно задовольняються потреби як суб'єктів, які їх надають, так й осіб, які їх отримують, а тому це можна вважати важливою ознакою послуги, що виокремлює їхню самостійність.

На думку T.I. Данилюк, послуга - це «діяльність, яка здійснюється для задоволення певних потреб або інших зручностей, наданих будь-кому» [16, с. 22]. Доречним $є$ визначення послуги як «процесу здійснення діяльності, адже сама сфера послуг має полісемантичний характер і включає різні види діяльності» [17, с. 242]. Під будь-якою послугою розуміється «діяльність, яка спрямована на задоволення певних потреб людини, тобто послуга - це дія, результат якої споживається в процесі iii надання» [18, с. 67]. Також висловлюється думка, що послуга - «певна діяльність, яка не пов'язана зі створенням речі (ii відновленням, ремонтом тощо), однак сама собою породжує відповідне благо, що має споживчу вартість, і завдяки своїм корисним властивостям здатна задовольняти певні потреби» [19, с. 235]. Ю.В. Коваленко вважає, що послуга - це «різнорідна економічна діяльність, що здійснюється виробником, задовольняє купівельний попит і потреби (особисті, колективні, суспільні), споживається в момент їі постачання й має фактичний відчутний результат» $[20$, с. 44]. У словнику послуга також виокремлюється як дія, вчинок, що дає користь, допомогу іншому [21, с. 342]. Деякі автори виокремлюють послугу як товар. Так, наприклад, на думку C.I. Плакида, послуга - це «специфічний товар інфраструктурного характеру, який відображений у діяльності, пов'язаній із забезпеченням нормального або більш ефективного функціонування учасників ринку» $[22$, с. 242]. Тобто послуга пов'язується $з$ різноманітною господарською діяльністю, яка не заборонена та необмежена, що сприяє іiі різноманітності й ефективному стану ринкового середовища.

У ГК України послуги пов'язані з вартістю, тобто це також є їх кваліфікуючою самостійною ознакою. Вартісний характер також характеризує мету послуги суб'єкта, який ї надає, тобто, як правило, це отримання прибутку. Платність послуги пов'язується 3 тим, що вона визнається певним видом товару. Так, Л.І. Кущ зазначає, що «споживачами цих благ є не тільки громадяни як кінцеві споживачі, а й різні організації, які використовують результати цієї діяльності для своїх господарських або інших потреб. Тому ці блага функціонують як товар і передаються всім споживачам виключно на платній основі» [23, с. 242]. Крім того, вартісний характер послуги дає 
змогу останній виступати в господарському обігу, бути конкурентоспроможною, а суб'єкти, які іï надають, мають право на державну допомогу. Зазначене міститься в Рішенні Антимонопольного комітету України від 01.08.2019 р., а саме: «Для того, щоб мати вплив на економічну конкуренцію (спотворювати або загрожувати спотворенням конкуренціі), допомога суб'єктові господарювання повинна стосуватися діяльності такого суб'єкта щодо виробництва товару (виконання робіт, надання послуг), який має вартісний характер і цінову визначеність та бере участь у господарському обороті на ринку» [24].

Отже, послуги у сфері господарювання - це економіко-соціальна професійна діяльність, змістом якої $€$ сукупність певних дій, що надаються певними суб'єктами (вузькопрофільними спеціалістами), які, як правило, реалізуються (споживаються) під час їх здійснення (надання) на платних засадах. Ознаками послуг у сфері господарювання є економіко-соціальний характер, задоволення потреб споживачів послуг, вартісний характер, споживання під час надання, видова різноманітність і конкурентоздатність. Доречним є доповнення ст. 1 Закону України «Про технічні регламенти та оцінку відповідності» від 15.01.2015 визначенням послуги як результату економічної діяльності, яка не створює товар, але продається та купується під час торговельних та інших операцій.

У статті досліджено нормативне визначення змісту господарської діяльності, у якому виокремлюється складник предмета господарського права - надання послуг вартісного характеру як самостійної правової категорії. Послуги є привабливою та поширеною формою господарювання, метою надання яких $є$, як правило, отримання прибутку або задоволення економіко-соціальних потреб. Деякі послуги є формою владно-розпорядчих повноважень спеціально уповноважених державних органів, наприклад, стосовно легалізації суб’єктів господарювання або/ma їхньої діяльності.

Здійснено обтрунтування уніфікованого підходу до розуміння сутності поняття «послуга» задля окреслення фундаментальних засад щодо іï змістової характеристики, умов $i$ порядку застосування та регулювання в умовах ринкової економіки. Для ефективного розвитку й удосконалення інституту послуг необхідним є зоійснення постійного моніторинау задля виявлення попиту на будь-які послуги або задоволення сучасних економіко-соціальних потреб.

Проаналізовано такі положення: послуга використовується різноманітними галузями права (адміністративним правом, ццивільним, земельним, фінансовим $i$ господарським правом), щцо дає змогу виокремити ї комплексний характер; суб'єкти господарювання є особами, які надають послуги на умовах $i$ в порядку, визначених нормами чинного законодавства, з урахуванням міжнародного досвіду. Також виокремлюються особи, які є споживачами послуг i/ або ї замовниками, якими також можуть бути й суб'єкти господарювання. Специфічними ознаками послуги $є$ такі: споживання в момент ї надання, вартісний характер, економіко-соиіальний характер, договірна форма.

Ключові слова: послуга, вартісний характер, потреби, сфера господарювання, економічно-суспільні потреби, чинне законодавство, предмет господарського права.

Dyshkantiuk Yu. Concepts and marks of the service as a subject of economic and legal regulation

The article investigates the normative definition of the content of economic activity, which distinguishes the component of the subject of business law - the provision of services of value nature as an independent legal 
category. Services are an attractive and widespread form of business, the purpose of which is to provide, as a rule, profit or economic and social needs. Some services are a form of authority and authority of specially authorized state bodies, for example, in the legalization of economic entities or/and their activities.

The unified approach tounderstanding the essence of the concept of "service" is grounded in order to outline the fundamental principles regarding its substantive characteristics, conditions and procedure of application and regulation in a market economy. For the effective development and improvement of the Institute of Services, it is necessary to carry out continuous monitoring to identify the demand for any services or to meet the current economic and social needs.

The following provisions are analyzed: the service is used by various branches of law (administrative law, civil, land, financial and business law), which allows to distinguish its complex nature; economic entities are persons who provide services on the terms and in accordance with the rules of the current legislation, taking into account international experience. Also distinguished are persons who are consumers of services and/or their customers, who may also be business entities. Specific features of the service are the following: consumption at the time of its provision, value, economic and social nature, contractual form.

Key words: service, cost character, needs, economic sphere, economic and social needs, current legislation, subject of business law.

\section{Література}

1. Господарський кодекс України : Закон України від 16 січня 2003 р. Офічійний вісник України. 2003. № 11. Ст. 462.

2. Гражданский кодекс Польской Народной Республики : Закон от 23 апреля 1964 года. Москва: Прогресс, 1966. 373 с.

3. Про свободу господарської діяльності : Закон Польської Народної Респу- бліки від 2 липня 2004 р. URL: https:// lublin.mfa.gov.ua/.

4. Про захист прав споживачів : Закон України від 12 травня 1991 р. Відомості Верховної Ради України. 1991. № 30. Ст. 379.

5. Про технічні регламенти та проиедури оцінки відповідності : Закон України від 1 грудня 2005 р. Відомості Верховної Ради України. 2006. № 12. Сm. 101 (утратив чинність).

6. Про затвердження Положення про порядок відбору осіб, які можуть виконувати роботи (надавати послуги) неплатоспроможним банкам або банкам, що ліквідуються, Фондом гарантування вкладів фізичних осіб : Рішення Виконавчої дирекиіï Фонду гарантування вкладів фізичних осіб від 28 березня 2016 р. № 434. Офіиійний вісник України. 2016. № 40. Ст. 1531.

7. Шереметьєва Л.А., Бец̧а I.I. Концепmуальні підходи, типи та види державних послуг в Європейському Союзі та в Україні: порівняльний аналіз / Національна академія державного управління при Президентові України. URL: http: / / wrw.academy.gov.ua/.

8. Конституційні акти Европейського Союзу (в редакиї Лісабонського договору) / пер. Г. Друзенка та С. Друзенко ; за заг. ред. Г. Друзенка. Київ : K.I.C., 2010. C. 80, 97-101, 389.

9. Single market for services (White Paper on Services of General Interest, Services Directive. URL: http: / / europa.eu/legislation_ summaries/internal_market/single_market_.

10. Про деякі правові аспекти інформаційних послуг, зокрема електронноі комериії, на внутрішньому ринку : Директива Європейського парламенту та Ради від 8 червня 2000 p. 2000/31/EC. URL: https:zakon.rada.gov.ua/.

11. Про здійснення закупівель суб'єктами, що здійснюють діяльність у сфері водопостачання, енергетики, транспорту та поштових послуг, шо припиняе дію Директиви 2014/25/EC : Директива Європейського парламенту та Ради від 26 лютого 2014 p. 2000/31/EC. URL: https:zakon.rada.gov.ua/.

12. Case law of the Court of Justice of the European Communities and Commission Decisions. URL: http: / / www.tem.fi/index.phtm.

13. Співак Л.С. Формування ринку послуг в трансформаційній економіці : дис. ... канд. екон. наук : 08.01.01. Київ, 2002. $192 \mathrm{c}$.

14. Россинский М.Б. Сфера услуг в экономике развитого соииализма. Саратов : Изд-во Саратовс. ун-та, 1976. 152 с. 


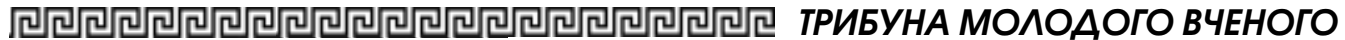

15. Агабабьян Э.М. Экономический анализ сферы услуг. Москва: Экономика, 1968. $160 \mathrm{c}$.

16. Данилюк T.I. Сутність поняття «послуга»: теоретичні аспекти. Ефективна економіка. 2014. № 8. С. 10-15.

17. Плакида C.I. Cутність поняття «послуги»: теоретичні аспекти. Інноваиійна економіка. 2013. № 6. С. 241-243.

18. Електронне урядування та електронна демократія : навчальний посібник : у 15 ч. / за заг. ред. А.I. Семенченка, В.М. Дрешпака. Київ, 2017. Частина 10: Електронні послуги / P.M. Матвійчук, С.П. Кандзюба. Київ : ФОП Москаленко O.M., 2017. $60 \mathrm{c}$.

19. Рєзнікова В.В. Послуга як правова категорія та ознака посередницьких договорів. Університетські наукові записки. 2007. № 4 (24). С. 234-240.
20. Коваленко Ю. Теоретичні аспекти сутності послуги та ї види. Вісник KHTEУ. 2012. № 2. С. 38-47.

21. Словник украӥнської мови : в $11 \mathrm{~m}$. Киї, 1976. T. 7. С. 342 .

22. Плакида C.I. Сутність поняття «послуга»: теоретичні аспекти. Інноваційна економіка. 2013. № 6. С. 241-243.

23. Куш Л.І. До питання про поняття господарської діяльності в охороні здоров'я. Медичне право України: проблеми становлення та розвитку : матеріали I Всеукраїнської наук.практ. конф. (19-20 квіт. 2007 р., м. Львів). Львів : Медицина і право. 2007. С. 179-183.

24. Про визнання підтримки суб'єктів господарювання, зазначеної у повідомленні, такою, що не є державною допомогою відповідно до Закону : Рішення Антимонопольного комітету України від 1 серпня 2019 p. URL: http: / / www.amc.gov.ua/. 